\title{
Using Dicamba in Dicamba-Tolerant Crops ${ }^{1}$
}

\author{
J. Ferrell and R. Leon²
}

After many years in development, dicamba will likely be fully approved for use in tolerant cotton varieties for the 2017 growing season. There is great concern that dicamba drift can result in significant losses in nearby sensitive crops. This concern is well-founded because many crops (such as soybean, snap bean, and peanut) are highly sensitive to extremely low doses of dicamba. All precautions must be followed if these new dicamba formulations are to be used. A few important considerations are herbicide selection, discontinued use of ammonium sulfate, nozzle selection, wind speed, and boom height.

\section{Herbicide Selection}

Dicamba has been available and widely used in corn, small grain, and pastures for over 50 years. There are many different brands of dicamba in the marketplace. However, it is essential that only products approved for use in dicamba-tolerant crops be used. The approved herbicides will be XtendiMax from Monsanto, Engenia from BASF, and FeXapan from DuPont. These specific herbicides must be used because they have been engineered to have very low volatility, or potential to turn into a gas after application, while maintaining full herbicidal potency, unlike the common "Banvel-type" herbicides. Using a "Banvel-type" herbicide over the top of cotton or soybeans would be illegal.

\section{Ammonium Sulfate}

Ammonium sulfate should never be added with XtendiMax, Engenia, or FeXapan. Adding ammonium sulfate, the principal component of many water conditioners sold at the retail level, creates unique chemical forces in the spray solution that convert low-volatility dicamba into a form with equal or greater volatility than Banvel. Adding any ammonium sulfate product removes all the safety that has been engineered into the XtendiMax, Engenia, and FeXapan formulations.

\section{Nozzle Selection}

Nozzles create a range of droplet sizes from large to small. The number of small droplets formed and those small droplets' ability to drift are issues that users of each nozzle must take into account. The EPA has reviewed many different nozzles over a wide range of operating pressures. This information indicates that only certain nozzles and pressure combinations are appropriate for application of herbicides such as XtendiMax, Engenia, and FeXapan. For a current list of approved nozzles for XtendiMax, visit http://www.xtendimaxapplicationrequirements.com/Pages/ default.aspx. This list will continue to be updated, so it will be helpful to routinely check this website and the Engenia Herbicide Tank Mix Selector tool (http://agproducts.basf. us/campaigns/engenia/tankmixselector/) for the most

1. This document is SS-AGR-412, one of a series of the Agronomy Department, UF/IFAS Extension. Original publication date February 2017. Visit the EDIS website at http://edis.ifas.ufl.edu.

2. J. Ferrell, professor, Agronomy Department, UF/IFAS Extension, Gainesville, FL 32611; and R. Leon, assistant professor, Agronomy Department, UF/IFAS West Florida Research and Education Center, Milton, FL 32583; UF/IFAS Extension, Gainesville, FL 32611.

The use of trade names in this publication is solely for the purpose of providing specific information. UF/IFAS does not guarantee or warranty the products named, and references to them in this publication do not signify our approval to the exclusion of other products of suitable composition. All chemicals should be used in accordance with directions on the manufacturer's label.

The Institute of Food and Agricultural Sciences (IFAS) is an Equal Opportunity Institution authorized to provide research, educational information and other services only to individuals and institutions that function with non-discrimination with respect to race, creed, color, religion, age, disability, sex, sexual orientation, marital status, national origin, political opinions or affiliations. For more information on obtaining other UF/IFAS Extension publications, contact your county's UF/IFAS Extension office. 
current information. It is important to note that use of any nozzle not specifically approved and listed on these websites would be considered a misuse.

\begin{tabular}{|c|c|c|c|c|c|c|c|c|c|c|c|}
\hline \multicolumn{12}{|l|}{ Nozzles } \\
\hline \multirow[b]{2}{*}{ Manufacturer } & \multirow[b]{2}{*}{ Nozzle Type } & \multicolumn{9}{|c|}{ Operating Pressure (psi) } & \\
\hline & & 10 & 20 & 30 & 40 & 50 & 60 & 70 & 80 & 90 & 100 \\
\hline \multirow{6}{*}{$\begin{array}{l}\text { Greenleaf } \\
\text { Technologies }\end{array}$} & \begin{tabular}{|l|} 
TADF-D11003 \\
\end{tabular} & & Min 20 & & $\operatorname{Max}_{40}$ & & & & & & \\
\hline & TADF-D11006 & & Min 20 & & & $\begin{array}{c}\text { Max } \\
50\end{array}$ & & & & & \\
\hline & TDXL-D11003 & & Min 20 & & $\operatorname{Max}_{40}$ & & & & & & \\
\hline & TDXL-D11004 & & Min 20 & & & $\operatorname{Max}$ & & & & & \\
\hline & TDXL-D11005 & & Min 20 & & & & $\operatorname{Max}$ & & & & \\
\hline & TDXL-D11006 & & Min 20 & & & & $\operatorname{Max}_{60}$ & & & & \\
\hline \multirow{2}{*}{ Hypro } & ULD12004 & & Min 20 & & Max & & & & & & \\
\hline & ULD12005 & & Min 20 & & Max & & & & & & \\
\hline \multirow{4}{*}{ Lechler } & ID11003 & & & Min 30 & $\max _{40}$ & & & & & & \\
\hline & ID11004 & & & Min 30 & Max & & & & & & \\
\hline & ID11005 & & & $\operatorname{Min} 30$ & Max & & & & & & \\
\hline & 108004 & & & Min 30 & $\operatorname{Max}_{40}$ & & & & & & \\
\hline \multirow{7}{*}{$\begin{array}{l}\text { Toeletet8 } \\
\text { Technologies }\end{array}$} & AI11003 & & & Min 30 & $\operatorname{Max}_{40}$ & & & & & & \\
\hline & At8003 & & & Min 30 & $\begin{array}{l}\operatorname{Max} \\
40\end{array}$ & & & & & & \\
\hline & At8005 & & & Min 30 & $\operatorname{Max}_{40}$ & & & & & & \\
\hline & $\pi 111003$ & & $\operatorname{Min} 20$ & & & & $\operatorname{Max}_{60}$ & & & & \\
\hline & m111004 & & Min 20 & & & & $\begin{array}{c}\text { Max } \\
63\end{array}$ & & & & \\
\hline & $\pi 111005$ & & Min 20 & & & & $\operatorname{Max}_{60}$ & & & & \\
\hline & $\pi 111006$ & & Min 20 & & & $\begin{array}{c}\text { Max } \\
50\end{array}$ & & & & & \\
\hline Wilger & DR11010 & & Min 20 & & $\operatorname{Max}_{40}$ & & & & & & \\
\hline
\end{tabular}

Figure 1. List of nozzles and pressures that can be used to apply XtendiMax herbicide.

Credits: Reprinted with written permission from Monsanto. Accessed on February 21, 2017. http://www.xtendimaxapplicationrequirements. com/Pages/default.aspx.

\section{Boom Height}

Controlling the height of the spray boom above the crop is essential to reducing drift. The droplet is less likely to move off-site if it has to travel a shorter distance. For this reason, a maximum boom height of 24 inches above the soil surface or the crop canopy is required. Exceeding this height dramatically increases drift potential.

\section{Wind Speed}

It is essential to pay close attention to wind speeds before and during any dicamba application. The final ruling on the maximum wind speed has yet to be finalized, but it will likely be $10 \mathrm{mph}$. XtendiMax, Engenia, and FeXapan will probably not be exempt from the $10 \mathrm{mph}$ maximum wind speed that has been in the Florida Organo-Auxin Herbicide Rule (Florida Department of Agriculture and Consumer Services 2010) for over 30 years. Any part of this rule that remains active for XtendiMax, Engenia, and FeXapan will have precedent over any label language. You will need to check the State of Florida label to confirm what that maximum speed is. Records of wind speed and direction will need to be kept closely. Spraying must cease if the wind speed is too high or if the wind blows toward a sensitive crop.

\section{Frequently Asked Questions Why are these restrictions important?}

This is a conditional Federal registration, which is quite uncommon. This means that the registration is time-limited and will expire in November of 2018. At that time, the EPA will assess how many drift complaints or fields with documented resistance have been filed and determine if these numbers are too high to justify the full registration of XtendiMax, Engenia, and FeXapan in cotton and soybeans. Therefore, it is essential to continue rotating herbicide chemistry and using preemergence herbicides to reduce the likelihood of resistance. It will also be essential to observe the buffer zone, nozzle selection, and wind speed requirements to ensure that drift does not occur.

\section{Can I continue to use conventional 2,4-D or dicamba formulations?}

Yes. However, you must follow the instructions on the label for that specific herbicide. For example, Banvel must be applied 21 days (plus rainfall) before cotton can be planted. XtendiMax can be applied preplant or at planting in dicamba-resistant cotton. Older formulations may provide an economic advantage, but the new formulations will provide application flexibility. Regardless of which dicamba or 2,4-D product is used, the Florida Organo-Auxin Herbicide Rule (Florida Department of Agriculture and Consumer Services 2010) must be followed.

\section{Can I tank-mix dicamba (XtendiMax, Engenia, or FeXapan) with glufosinate or glyphosate?}

Currently, no. The EPA wants to make sure that these tank mixtures do not change the volatility profile of these dicamba formulations and produce off-target movement. Therefore, no tank-mix partners have been approved for 2017. However, these formulations should be used with other herbicides to broaden the spectrum. Our data has recently shown that applying XtendiMax or Engenia first followed by glufosinate one to three days later is more effective on Palmer amaranth than applying glufosinate followed by either dicamba or simply applying dicamba alone. 


\section{Are there special licensing requirements to purchase or apply these herbicides?}

It is likely that no additional training will be required to purchase or use these herbicides in Florida in 2017. However, if drift or misuse complaints are common in 2017, a training requirement will likely be imposed for 2018 .

\section{Are there special tank clean-out procedures?}

No. Traditional triple-rinse clean-out will be sufficient. However, you must not let dicamba sit in the sprayer overnight. Doing this will make it much more difficult to effectively clean the tank.

\section{Is special recordkeeping required to comply with the FDACS Organo-Auxin Herbicide Rule?}

No additional recordkeeping is likely to be required, but the same records associated with conventional dicamba product applications may need to be kept for XtendiMax, Engenia, and FeXapan for two years.

\section{References}

Florida Department of Agriculture and Consumer Services. 2010. "5E-2.033 Organo-Auxin Herbicides: Restrictions and Prohibitions." Florida Department of State Florida Administrative Code \& Florida Administrative Register. Accessed on February 20, 2017. https://www.flrules.org/ gateway/ruleno.asp?id=5E-2.033

Monsanto. 2016. “Nozzles.” XtendiMax ${ }^{\mathrm{Tm}}$ Herbicide with VaporGrip ${ }^{\text {in }}$ Technology. Accessed on February 21, 2017. http://www.xtendimaxapplicationrequirements.com/Pages/ default.aspx 